\title{
Physico-Chemical Indices, Iso- $\alpha$-Acid, Phenolic Contents and Antioxidant Activity of Commercial Beers
}

\author{
Antonietta Baiano $^{1} \&$ Carmela Terracone ${ }^{1}$ \\ ${ }^{1}$ University of Foggia, Foggia, Italy \\ Correspondence: Antonietta Baiano, University of Foggia, Foggia, Italy. Tel: 39-088-158-9249. E-mail: \\ a.baiano@unifg.it
}

Received: February 5, 2013 Accepted: May 31, 2013 Online Published: July 26, 2013

doi:10.5539/jfr.v2n4p107

URL: http://dx.doi.org/10.5539/jfr.v2n4p107

\begin{abstract}
The effects of brewing style on physicochemical indices, iso- $\alpha$-acids and antioxidant contents of commercial beers were investigated. A great variability was highlighted for all the considered parameters (sugar and alcohol contents, density, $\mathrm{pH}$, titratable acidity, iso- $\alpha$-acids, phenolic content, antioxidant activity). The beers having the highest iso- $\alpha$-acids contents were Guinness Special Export Stout (which also showed the highest phenolic content), Chimay Pères Trappistes Triple, and Greene King IPA whereas the lowest values were detected in Cuveè De Ranke, Heineken Premium Quality Lager, and Riedenburger Brauhaus gluten free. The latter also had the lowest phenolic concentration. The antioxidant activity values strictly correlated with the total phenolic content but not with the iso- $\alpha$-acid amount. The Principal Component Analysis failed in distinguishing beers based on their declared type/styles. This was a predictable result since the beer styles don't represent a compositional classification but they are rather used to indicate commercial types.
\end{abstract}

Keywords: antioxidant activity, beer, iso- $\alpha$-acid, phenolic content, physico-chemical indices

\section{Introduction}

Beer is the world's most widely consumed alcoholic beverage (European Beer Guide, 2006). It is generally produced by the brewing and fermentation of sugars (mainly derived from malted cereal grains such as barley and wheat but also from the cheaper corn and rice), and flavoured with hops, which add bitterness and act as a natural preservative. Other ingredients and flavouring agents may occasionally be included.

Beer style is a term used to categorize beers by various factors such as colour, flavour, strength, ingredients, production method, recipe, history, and origin. A first classification is made on the basis of fermentation. Yeasts fermenting at temperatures between 16 and $24{ }^{\circ} \mathrm{C}$ form a layer on the surface of the wort/beer. Based on this behaviour, they are referred to as "top-fermenting yeasts". These yeasts belong to the species Saccharomyces cerevisiae and the beers obtained in this way are known as "at high fermentation temperature" or Ale. Yeasts fermenting at temperatures around $10{ }^{\circ} \mathrm{C}$ collect at the bottom of the fermentation tank and are referred to as "bottom-fermenting yeast". These yeasts belong to the species Saccharomyces carlsbergensis and the beers obtained in this way are known as "at low fermentation temperature" or Lager. Two other types of beer styles include beers of spontaneous fermentation, namely Lambic which is mainly produced in Belgium, and beers of mixed origin that include Altbier and Kölsch. Brewing techniques, ingredients, and yeast used are the factors that determine the beer style. After fermentation, ale beers are usually aged a few weeks at temperatures from 14 to $18{ }^{\circ} \mathrm{C}$. For Lager beers, the aging temperatures are in the range $2-10{ }^{\circ} \mathrm{C}$ and maintained at this temperature for 6-12 days.

Ale, which is the oldest beer type, and Lager beers, developed by German brewers, are further classified in other beer styles based on ingredients used and processing applied. Ale beers include Barley Wine, Bitter, Brown Ale, India Pale Ale, Pale Ale, Porter, Stout, and Wheat Beer. Bock, Dunkel, Oktoberfest/Maerzen and Pilsner can be grouped within the Lagers. Nevertheless, the number of styles is continuously increasing as a consequence of process and product innovation.

Beer composition varies with style. An all-malt Pilsen beer has the following mean composition (Bamforth, 2004): water $919 \mathrm{~g} / \mathrm{L}$, total carbohydrate $28 \mathrm{~g} / \mathrm{L}$, carbon dioxide $5 \mathrm{~g} / \mathrm{L}$, proteins $5 \mathrm{~g} / \mathrm{L}$, alcohol $39.3 \mathrm{~g} / \mathrm{kg}$, low molecular weight $\mathrm{N}$ compounds $185 \mathrm{mg} / \mathrm{L}$, medium molecular weight $\mathrm{N}$ compounds $83 \mathrm{mg} / \mathrm{L}$, high molecular 
weight $\mathrm{N}$ compounds $26 \mathrm{mg} / \mathrm{L}$, potassium $493 \mathrm{mg} / \mathrm{L}$, sodium $30 \mathrm{mg} / \mathrm{L}$, calcium $34 \mathrm{mg} / \mathrm{L}$, magnesium $107 \mathrm{mg} / \mathrm{L}$, phosphorus $308 \mathrm{mg} / \mathrm{L}$, sulphate $176 \mathrm{mg} / \mathrm{L}$, chloride $179 \mathrm{mg} / \mathrm{L}$, nitrate $23 \mathrm{mg} / \mathrm{L}$, thiamine $33 \mu \mathrm{g} / \mathrm{L}$, riboflavin 410 $\mu \mathrm{g} / \mathrm{L}$, pyridoxin $650 \mu \mathrm{g} / \mathrm{L}$, pantothenic acid $1632 \mu \mathrm{g} / \mathrm{L}$, niacin $7875 \mu \mathrm{g} / \mathrm{L}$, biotin $13 \mu \mathrm{g} / \mathrm{L}$, vitamin $\mathrm{B}_{12} 0.1 \mu \mathrm{g} / \mathrm{L}$, folic acid $82 \mu \mathrm{g} / \mathrm{L}$, meso-inositol $10.1 \mathrm{mg} / \mathrm{L}$, choline $18.1 \mathrm{mg} / \mathrm{L}$, total polyphenols $172 \mathrm{mg} / \mathrm{L}$, anthocyans 46 $\mathrm{mg} / \mathrm{L}$, iso- $\alpha$-acids and other related molecules $10-40 \mathrm{mg} / \mathrm{L}$, and small amounts of biogenic amines. The majority of the phenolic content of beer comes from malt, but hop polyphenols contribute up to one third of the total phenolic load in beer and therefore have a considerable effect on flavour stability and also on bitterness. Phenolic compounds are of particular interest to brewers because they play a key role in the brewing process by delaying or preventing oxidation processes (Guido, Boivin, Benismail, Gonçalves, \& Barros, 2002). Phenolic profiles and antioxidant activity in barley varied across varieties and changed during malting (Lu et al., 2007; H. Zhao et al., 2008). Thus, the differences of raw materials and brewing process lead to significant differences in phenolic composition and antioxidant activities of beer. The hop $\alpha$-acids or humulones, which are almost tasteless, are isomerized into the bitter-tasting iso- $\alpha$-acids or isohumulones during the boiling process. During the brewing process, almost all $\beta$-acids are removed or oxidized, while each $\alpha$-acid is transformed into its corresponding mixture of iso- $\alpha$-acids (cis and trans isomers). Thus, six iso- $\alpha$-acids originate from the three main hop $\alpha$-acids. Tetrahydroiso- $\alpha$-acids also exist as cis and trans isomeric pairs, totalling six stereoisomers. Reduction of iso- $\alpha$-acids to dihydroiso- $\alpha$-acids introduces an additional chiral centre, leading to twelve stereomeric members of dihydroiso- $\alpha$-acids (Vanhoenacker, De Keukeleire, \& Sandra, 2004).

The main aim of this study was to investigate and contribute to knowledge of composition and antioxidant properties of some of the most important commercial beers in the light of the different brewing styles.

\section{Materials and Methods}

\subsection{Beer Samples}

Three bottles of 9 beer samples were purchased from local markets (Foggia, Italy). The detailed characteristics of these beers were presented in Table 1 . All samples were stored in a refrigerator at $4{ }^{\circ} \mathrm{C}$ and analysed within 48 h. Seven beers were chosen among those produced at high fermentation temperature whereas the other 2 belong to the group of the low fermentation beers.

Prior to analysis, samples were degassed by ultrasonication.

Table 1. Characteristics of the 9 commercial beers

\begin{tabular}{|c|c|c|c|}
\hline Brand & Type/Style & Raw materials & Country of Origin \\
\hline $\begin{array}{l}\text { Aecht Schlenkerla Rauchbier } \\
\text { Weizen }\end{array}$ & $\begin{array}{l}\text { (high fermentation) } \\
\text { Wheat beer }\end{array}$ & $\begin{array}{l}\text { Water, wheat malt, barley } \\
\text { malt, aroma hops and } \\
\text { top-fermenting Bavarian } \\
\text { style Wheatbeer yeast }\end{array}$ & Germany \\
\hline Greene King IPA Export & $\begin{array}{l}\text { (high fermentation) } \\
\text { Indian Pale Ale }\end{array}$ & $\begin{array}{l}\text { Water, barley malt, yeast } \\
\text { and hops }\end{array}$ & Great Britain \\
\hline Cuveè De Ranke & $\begin{array}{l}\text { (high fermentation } 70 \% / \\
30 \% \text { spontaneous } \\
\text { fermentation) } \\
\text { blend of } 70 \% \text { Belgian } \\
\text { Ale } 30 \% \text { lambic }\end{array}$ & $\begin{array}{l}\text { Blend } 70 / 30 \text { of beer } \\
\text { fermented with Rodenbach } \\
\text { yeasts aged } \\
\text { lambicinvecchiato supplied } \\
\text { by Girardin }\end{array}$ & Belgium \\
\hline Moretti Grand Cru & $\begin{array}{l}\text { (high fermentation) } \\
\text { Special }\end{array}$ & $\begin{array}{l}\text { Water, barley malt, yeast } \\
\text { and hops }\end{array}$ & Italy \\
\hline Chimay Pères Trappistes Triple & $\begin{array}{l}\text { (high fermentation) } \\
\text { Trappiste Belgian Ale }\end{array}$ & $\begin{array}{l}\text { Water, barley malt, wheat, } \\
\text { sugar, hop, yeast }\end{array}$ & Belgium \\
\hline Guinness Special Export Stout & $\begin{array}{l}\text { (high fermentation) } \\
\text { Stout }\end{array}$ & $\begin{array}{l}\text { Water, malted, flaked, and } \\
\text { roasted barley, hops, yeast }\end{array}$ & Ireland \\
\hline Grolsch Premium Lager & $\begin{array}{l}\text { (low fermentation) } \\
\text { Lager }\end{array}$ & $\begin{array}{l}\text { Water, barley malt, yeast } \\
\text { and hop }\end{array}$ & Holland \\
\hline Heineken Premium Quality Lager & $\begin{array}{l}\text { (low fermentation) } \\
\text { Lager }\end{array}$ & $\begin{array}{l}\text { Water, barley malt, a } \\
\text { special yeast and hop }\end{array}$ & Holland \\
\hline Riedenburger Brauhaus gluten free & $\begin{array}{l}\text { (high fermentation) } \\
\text { Belgian Speciality Ale }\end{array}$ & $\begin{array}{l}\text { Water, millet malt, agave } \\
\text { scyrup, hops, yeast }\end{array}$ & Germany \\
\hline
\end{tabular}




\subsection{Analysis of Beer Composition}

Soluble solids and density were measured by a densimeter. The titratable acidity was obtained by titration with $0.1 \mathrm{~N}$ sodium hydroxide, using phenolphthalein as indicator. The $\mathrm{pH}$ values were also measured using a Ion. Ion $/ \mathrm{ph} / \mathrm{mV} /$ Temperature bench meter (Oakton Instruments, Vernon Hills, IL, U.S.A). The alcohol content was determined using a distillation procedure and the successive measurement of the density of the hydroalcoholic distillate by means of a Gibertini apparatus (Novate, Italy). The dry matter was determined by evaporation of a known volume of beer in a water bath until a syrupy consistency was reached and then, in an oven at $105{ }^{\circ} \mathrm{C}$ until the constant weight was attained. The total nitrogen was determined according to the AOAC method. A nitrogen-to-protein conversion factor of 6.25 was used.

\subsection{Detection of $\alpha$-Acids, Iso- $\alpha$-Acids and Reduced Iso- $\alpha$-Acids}

The HPLC analysis was performed according to Vanhoenacker et al. (2004) on an apparatus consisting of a degasser mod. G1322A, a binary pump mod. G1312A, an autosampler mod. G1329A equipped with a $20-\mu \mathrm{L}$ loop, and a diode array detector mod. G1315D (Agilent, Santa Clara, CA, U.S.A.). Data were collected and processed through a 2DChemstation G2175BA Rev. B 0402 (Agilent, Santa Clara, CA, U.S.A.).

A portion of the degassed beer was filtered through a syringe filter $(0.45 \mu \mathrm{m}$, PTFE) prior to injection into two Zorbax Extend C18 columns, $150 \mathrm{~mm}$ length $\times 4.6 \mathrm{~mm}$ i.d., packed with $5 \mu \mathrm{m}$ particles (Agilent Technologies, Waldbronn, Germany), coupled in series. The mobile phase consisted of $5 \mathrm{mM}$ ammonium acetate in $20 \%(\mathrm{v} / \mathrm{v})$ ethanol adjusted to $\mathrm{pH} 9.95$ with ammonia (solvent A) and acetonitrile/ethanol 60/40 (v/v) (solvent B). The flow-rate was set at $1 \mathrm{~mL} / \mathrm{min}$ and gradient elution was performed. The gradient was the following: $0-3 \mathrm{~min}: 0 \%$ B isocratic, 3-4 min: 0-16\% B, 4-54 min: $16-40 \% \mathrm{~B}, 54-57 \mathrm{~min}$ : 40-95\% B, 57-65 min: $95 \%$ B isocratic. The column temperature was maintained at $35^{\circ} \mathrm{C}$. UV detection was performed at $256 \mathrm{~nm}$ (iso- $\alpha$-acids and reduced iso- $\alpha$-acids) and $330 \mathrm{~nm}$ ( $\alpha$ - and $\beta$-acids). Identification of HPLC-peaks was made by comparing elution order and relative retention time of the experimental data with those reported in literature (Vanhoenacker et al., 2004) and with those of the standards. Quantification of iso- $\alpha$-acids and tetrahydro-iso- $\alpha$-acids was made on the basis of calibration curves of external standards. The results were expressed as $\mathrm{mg} / \mathrm{L}$.

\subsection{Evaluation of the Total Phenolic Content}

The total phenolic content was measured at $765 \mathrm{~nm}$ through an UV-visible spectrophotometer (Varian Cary 50 SCAN, Palo Alto, CA, U.S.A.) according to the Folin-Ciocalteu method (Singleton \& Rossi, 1965). A calibration line was built on the basis of solutions at known and increasing concentrations of gallic acid (ExtraSynthese, Genay, France).

\subsection{Evaluation of Antioxidant Activity}

DPPH radical scavenging activity of beer was determined according to the method of Brand-Williams, Cuvelier, and Berset (1995) with minor changes. Sixty microliters of diluted beer samples were added to $1.75 \mathrm{~mL}$ of $6 \mathrm{x}$ $10^{-5} \mathrm{~mol} / \mathrm{L}$ DPPH solution (dissolved in $50 \%$ methanol solution). The absorbance at $517 \mathrm{~nm}$ was measured after the solution remained in the dark for $60 \mathrm{~min}$. The Trolox calibration curve was plotted as a function of the percentage of DPPH radical scavenging activity. The final results were expressed as TEAC (Trolox Equivalent Antioxidant Capacity).

\subsection{Statistical Analysis}

At least 5 replicates were performed for each analyses. The averages and the standard deviations were calculated by the Excel software ver. 11.5.1 (Microsoft, Redmond, WA). The Analysis of Variance (One-way ANOVA) at $p<0.05$ followed by the LSD test was applied to highlighted significant differences among samples. In order to highlight relationships between total phenolic content and antioxidant activity, a linear regression analysis were performed. The relative correlation coefficients $\mathrm{R}$ was reported at $p<0.05$. PCA was applied to separate the beer samples according to all parameters for which significant differences were highlighted. Among the eigenvectors, those showing absolute values higher than 0.20 were adopted to explain the projection of the samples on the factor-plane. The data were autoscaled before analysis. All the statistical analyses were made by the software Statistica, ver. 5.1 (Statsoft, Tulsa, OK).

\section{Results and Discussion}

\subsection{Beer Composition}

Table 2 shows the composition of the beers object of the study. It can be observed that the sugar contents varied over a wide range, with the lowest and highest values detected on the Grolsch Premium Lager and Guinness Special Export Stout, respectively. Furthermore, the low fermentation beers showed lowest sugar contents than 
the high fermentation ones. Also density showed a great variability, with values ranging from 3 (Cuveè De Ranke) and $26^{\circ}$ Oeschle (Riedenburger Brauhaus gluten free). This parameter could be used as an indirect index of the alcohol produced during fermentation since higher alcohol contents generally correspond to lower density values. The lowest $\mathrm{pH}$ and the highest titratable acidity were measured on Cuveè De Ranke samples. This finding was explained on the basis of the distinctive composition of the cuveè that was made with $30 \%$ of a lambic beer, produced by spontaneous fermentation and thus characterized by a strong acidity perceived as a freshness perception at the sensorial analysis. The Belgian laws stipulate that lambic beers must have acidity and volatile acidity values equal to or higher than 30 and 2 meq of $\mathrm{NaOH} 0.1 \mathrm{~N}$, respectively (Belgian Royal Decree, 1993). The lowest acidity was detected on the samples of the Guinness Special Export Stout beer. This characteristic, together with the foam creaminess is responsible for its smoothness.

Table 2. Soluble solid content, $\mathrm{pH}$, titratable acidity and $\%$ alcohol

\begin{tabular}{lccccc}
\hline \multicolumn{1}{c}{ Brand } & $\begin{array}{c}\text { Soluble solid } \\
\text { content }\left({ }^{\circ} \mathbf{P}\right)\end{array}$ & $\begin{array}{c}\text { Density } \\
\left({ }^{\circ} \text { Oeschle) }\right.\end{array}$ & pH & $\begin{array}{c}\text { Titratable } \\
\text { acidity } \\
\text { (g lactic } \\
\text { acid/100 mL) }\end{array}$ & $\begin{array}{c}\text { Alcohol content } \\
\text { measured (\% v/v) }\end{array}$ \\
\hline Aecht Schlenkerla Rauchbier & $6.8 \pm 0.0 \mathrm{~d}$ & $12 \pm 2 \mathrm{~d}$ & $4.31 \pm 0.05 \mathrm{e}$ & $0.15 \pm 0.01 \mathrm{~b}$ & $4.43 \pm 0.02 \mathrm{~b}$ \\
Weizen & $6.1 \pm 0.1 \mathrm{c}$ & $13 \pm 1 \mathrm{~d}$ & $3.87 \pm 0.02 \mathrm{~b}$ & $0.52 \pm 0.01 \mathrm{f}$ & $5.30 \pm 0.01 \mathrm{e}$ \\
Greene King IPA Export & $6.2 \pm 0.1 \mathrm{c}$ & $3 \pm 0 \mathrm{a}$ & $3.48 \pm 0.01 \mathrm{a}$ & $1.24 \pm 0.06 \mathrm{~g}$ & $7.10 \pm 0.03 \mathrm{~g}$ \\
Cuveè De Ranke & $7.2 \pm 0.0 \mathrm{e}$ & $9 \pm 0 \mathrm{c}$ & $4.17 \pm 0.04 \mathrm{c}$ & $0.44 \pm 0.01 \mathrm{e}$ & $7.00 \pm 0.02 \mathrm{f}$ \\
Moretti Grand Cru & $7.4 \pm 0.0 \mathrm{e}$ & $4 \pm 1 \mathrm{a}$ & $4.48 \pm 0.01 \mathrm{f}$ & $0.27 \pm 0.03 \mathrm{c}$ & $7.86 \pm 0.04 \mathrm{~h}$ \\
Chimay Pères Trappistes Triple & $9.6 \pm 0.0 \mathrm{f}$ & $14 \pm 2 \mathrm{~d}$ & $4.15 \pm 0.01 \mathrm{c}$ & $0.07 \pm 0.00 \mathrm{a}$ & $7.98 \pm 0.01 \mathrm{i}$ \\
Guinness Special Export Stout & $5.2 \pm 0.0 \mathrm{a}$ & $6 \pm 1 \mathrm{~b}$ & $4.25 \pm 0.00 \mathrm{~d}$ & $0.36 \pm 0.02 \mathrm{~d}$ & $4.90 \pm 0.01 \mathrm{~d}$ \\
Grolsch Premium Lager & $5.4 \pm 0.0 \mathrm{~b}$ & $6 \pm 0 \mathrm{~b}$ & $4.25 \pm 0.02 \mathrm{~d}$ & $0.36 \pm 0.01 \mathrm{~d}$ & $4.63 \pm 0.01 \mathrm{c}$ \\
Heineken Premium Quality Lager & $6.7 \pm 0.0 \mathrm{~d}$ & $26 \pm 2 \mathrm{e}$ & $4.11 \pm 0.03 \mathrm{c}$ & $1.39 \pm 0.05 \mathrm{~h}$ & $3.60 \pm 0.02 \mathrm{a}$ \\
Riedenburger Brauhaus gluten free & & & & & \\
\hline
\end{tabular}

In column. different letters indicate significant differences at $p<0.05$ by LSD multiple range test.

The RiedenburgerBrauhaus gluten free and Guinness Special Export Stout beers showed the lowest and the highest alcohol content, respectively. A low alcohol content is typical of low-gluten or gluten free beers. This finding could be related to the different sugar composition and thus to the different sugar-alcohol conversion factors of the various raw-materials. This behaviour was already observed during biomass-to-alcohol production that gave rise to the setting of a theoretical ethanol yield calculator (NREL, 2007).

The highest and lowest dry matter contents were detected on Guinness Special Export Stout and Grolsch Premium Lager beers, respectively (Table 3). Concerning the total nitrogen or protein content, the lowest values were detected on the Riedenburger Brauhaus gluten free beer whereas the highest values were measured on the samples of Chimay Pères Trappistes Triple (when expressed per L of beer) and on the Chimay Pères Trappistes Triple and Cuveè De Ranke beers (when expressed per kg of dry matter). Besides proteins, the beer nitrogen content also includes a number of polypeptides having molecular masses between 5 and $100 \mathrm{kDa}$ and mainly deriving from barley protein as a consequence of proteolysis and chemical changes taking place during brewing and a great amount of peptides $(6-7 \mathrm{kDa})$. The concentration of proteins, polypeptides, and peptides is known to affect beer quality to a large measure. Polypeptides are involved in both clouding and foam stability. The simultaneous presence of hydrophilic and hydrophobic groups allows polypeptides to come through the liquid layer between bubbles and interact with gas and the hydrophobic groups of other molecules (Curioni, Pressi, Furegon, \& Peruffo, 1995). One of the most important characteristics of the proteins that promote foaming is their hydrophobicity. Interactions between hydrophobic proteins containing higher than 30\% of glutamine and proline and some polyphenols are responsible for clouding (Asano, Shinagawa, \& Hashimoto, 1982). 
Table 3. Dry matter, nitrogen and protein contents of the beers

\begin{tabular}{|c|c|c|c|c|c|}
\hline \multirow{2}{*}{ Brand } & \multirow{2}{*}{$\begin{array}{l}\text { \% Dry } \\
\text { matter } \\
(w / v)\end{array}$} & \multicolumn{2}{|c|}{ mg total nitrogen per } & \multicolumn{2}{|c|}{ g proteins per } \\
\hline & & L beer & kg dry matter & L beer & kg dry matter \\
\hline $\begin{array}{l}\text { Aecht Schlenkerla Rauchbier } \\
\text { Weizen }\end{array}$ & $5.1 \pm 0.0 \mathrm{~d}$ & $762 \pm 0 \mathrm{f}$ & $14863 \pm 0 \mathrm{e}$ & $4.7 \pm 0.0 \mathrm{f}$ & $92.9 \pm 0.0 \mathrm{e}$ \\
\hline Greene King IPA Export & $4.8 \pm 0.1 \mathrm{c}$ & $325 \pm 8 b$ & $6781 \pm 165 b$ & $2.0 \pm 0.0 \mathrm{~b}$ & $42.3 \pm 1.0 \mathrm{~b}$ \\
\hline Cuveè De Ranke & $3.6 \pm 0.1 \mathrm{a}$ & $781 \pm 133 \mathrm{f}, \mathrm{g}$ & $21534 \pm 3678 \mathrm{f}$ & $4.9 \pm 0.8 \mathrm{f}$ & $134.6 \pm 23.0 \mathrm{f}$ \\
\hline Moretti Grand Cru & $5.1 \pm 0.1 \mathrm{~d}$ & $552 \pm 20 \mathrm{e}$ & $10827 \pm 389 \mathrm{c}$ & $3.4 \pm 0.1 \mathrm{e}$ & $67.7 \pm 2.4 \mathrm{c}$ \\
\hline Chimay Pères Trappistes Triple & $4.6 \pm 0.3 \mathrm{c}$ & $919 \pm 92 \mathrm{~h}$ & $19985 \pm 1995 \mathrm{f}$ & $5.7 \pm 0.6 \mathrm{~h}$ & $124.9 \pm 12.5 \mathrm{f}$ \\
\hline Guinness Special Export Stout & $6.7 \pm 0.1 \mathrm{f}$ & $821 \pm 131 \mathrm{~g}$ & $12342 \pm 1966 \mathrm{e}$ & $5.1 \pm 0.8 \mathrm{~g}$ & $77.1 \pm 12.3 \mathrm{e}$ \\
\hline Grolsch Premium Lager & $3.5 \pm 0.0 \mathrm{a}$ & $457 \pm 4 d$ & $13033 \pm 113$ e & $2.8 \pm 0.0 \mathrm{~d}$ & $81.4 \pm 0.7$ e \\
\hline Heineken Premium Quality Lager & $4.0 \pm 0.0 \mathrm{~b}$ & $395 \pm 44 \mathrm{c}$ & $9939 \pm 1097 \mathrm{~d}$ & $2.5 \pm 0.3 \mathrm{c}$ & $62.1 \pm 6.9 \mathrm{~d}$ \\
\hline Riedenburger Brauhaus gluten free & $6.1 \pm 0.1 \mathrm{e}$ & $165 \pm 4 \mathrm{a}$ & $2711 \pm 65 \mathrm{a}$ & $1.0 \pm 0.0 \mathrm{a}$ & $16.9 \pm 0.4 \mathrm{a}$ \\
\hline
\end{tabular}

In column. different letters indicate significant differences at $p<0.05$ by LSD multiple range test. Nitrogen-to-protein conversion factor: 6.25 .

\section{$3.2 \alpha$-Acids, Iso- $\alpha$-Acids and Reduced Iso- $\alpha$-Acids}

The experimental data concerning these compounds are shown in Table 4 while Figure 1 shows the chromatograms referred to all the beer samples. Among the acids deriving from hops, the $\beta$-acids were not detected because they are usually oxidized in the lupulin glands or removed as a consequence of their insolubility. Analyses highlighted the presence of only one $\alpha$-acid namely cohumulone (A1). This compound was detected in all the beer samples, though in a wide range of values, depending on beer style and brand (the lowest concentrations in the Heineken Premium Quality Lager and RiedenburgerBrauhaus gluten free beers and the highest ones in the Aecht Schlenkerla Rauchbier Weizen beers).During brewing, the tasteless hop $\alpha$-acids isomerize into the corresponding bitter iso- $\alpha$-acid forms, which also have bacteriostatic activity and are involved in the improvement of the foam stability. Furthermore, these compounds could be responsible of off-flavour such as the well known "lightstruck".The reduced iso- $\alpha$-acids (dihydro-iso-humulones and tetrahydro-iso-humulones) are often used in brewing in order to improve the foam stability.The only iso- $\alpha$-acids detected in beer samples were the cis-isocohumulone (IAA1) and the trans-isocohumulone (IAA2) that co-eluted with the cis-dihydro-isoadhumulone (DH5). Greene King IPA Export and Guinness Special Export Stout beers showed the highest concentrations of these compounds.In particular, the average concentrations of IAA1, expressed as $\mathrm{mg} / \mathrm{L}$, were in decreasing order: Guinness Special Export Stout 34.3, Greene King IPA Export 29.9, Chimay Pères Trappistes Triple 24.2, Cuveè De Ranke 17.5, Moretti Grand Cru 13.8, Grolsch Premium Lager 12.3, and RiedenburgerBrauhaus gluten free 10.1. IAA1 was not detected in the Aecht Schlenkerla Rauchbier Weizen and in the Heineken Premium Quality Lager beers. 
Table 4. Areas of the peaks of $\alpha$-acids, iso- $\alpha$-acids, and reduced iso- $\alpha$-acids in beer samples. The retention times, expressed as min, are reported within brackets

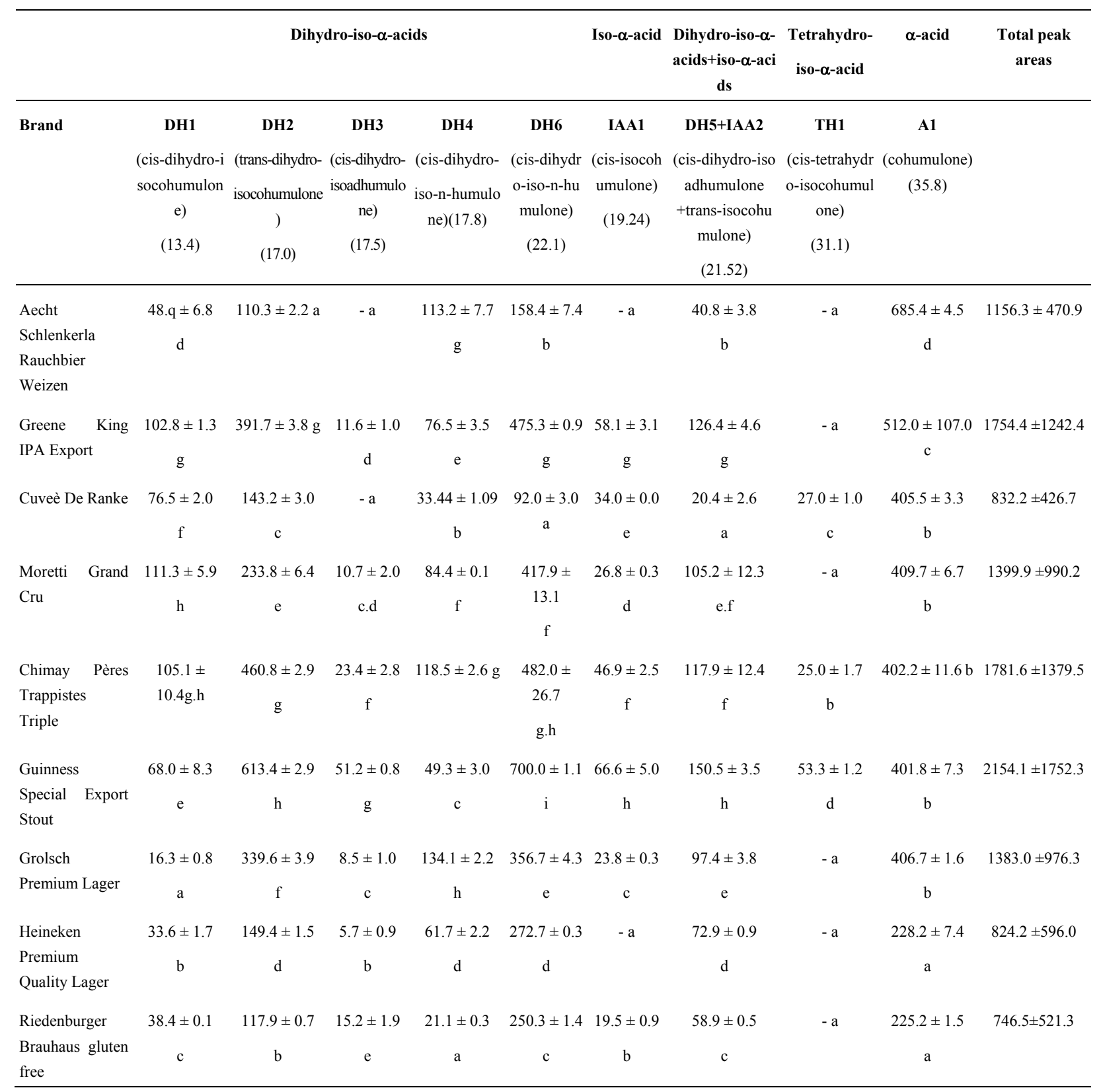

In column, different letters indicate significant differences at $p<0.05$ by LSD multiple range test. 

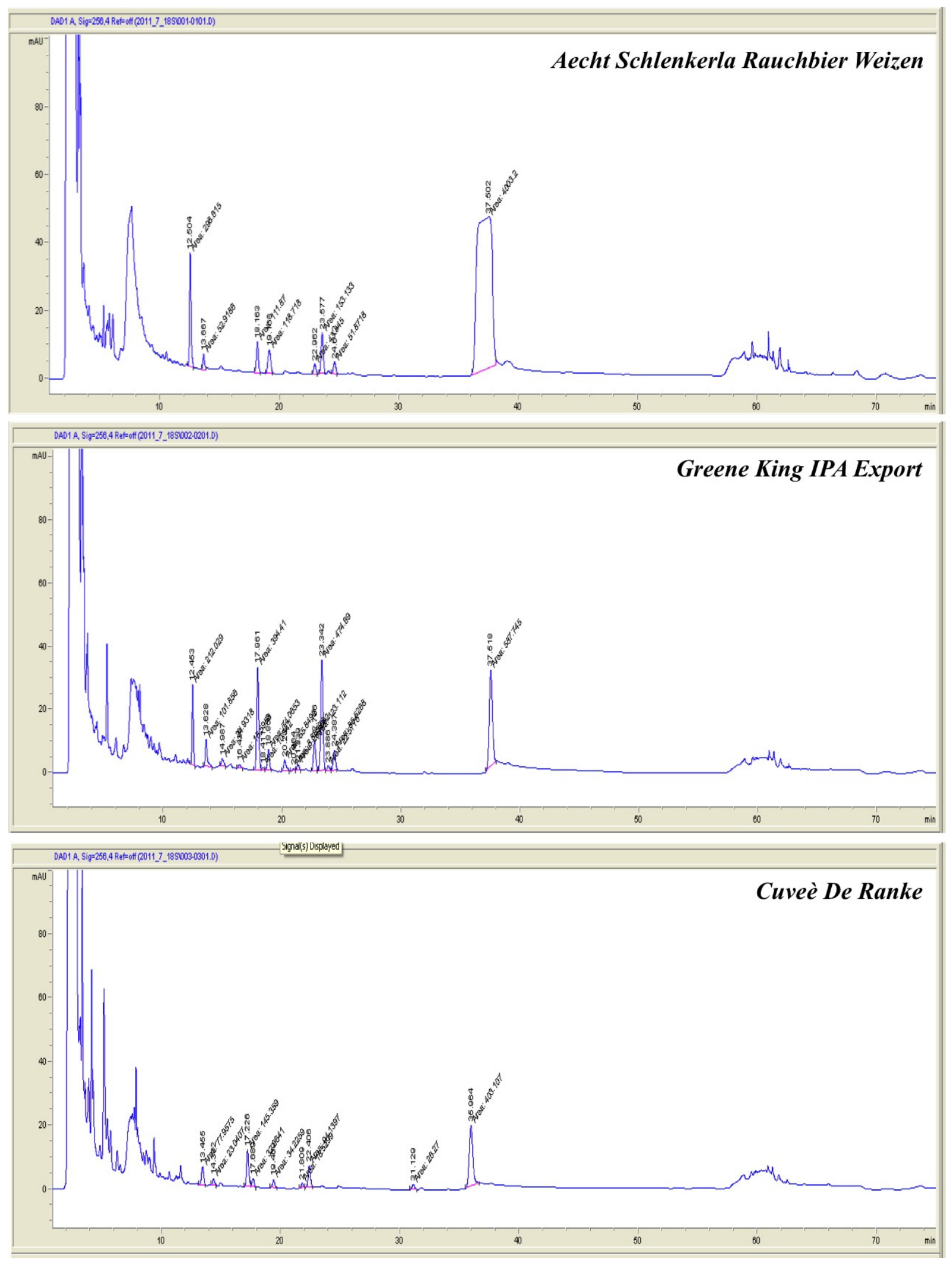

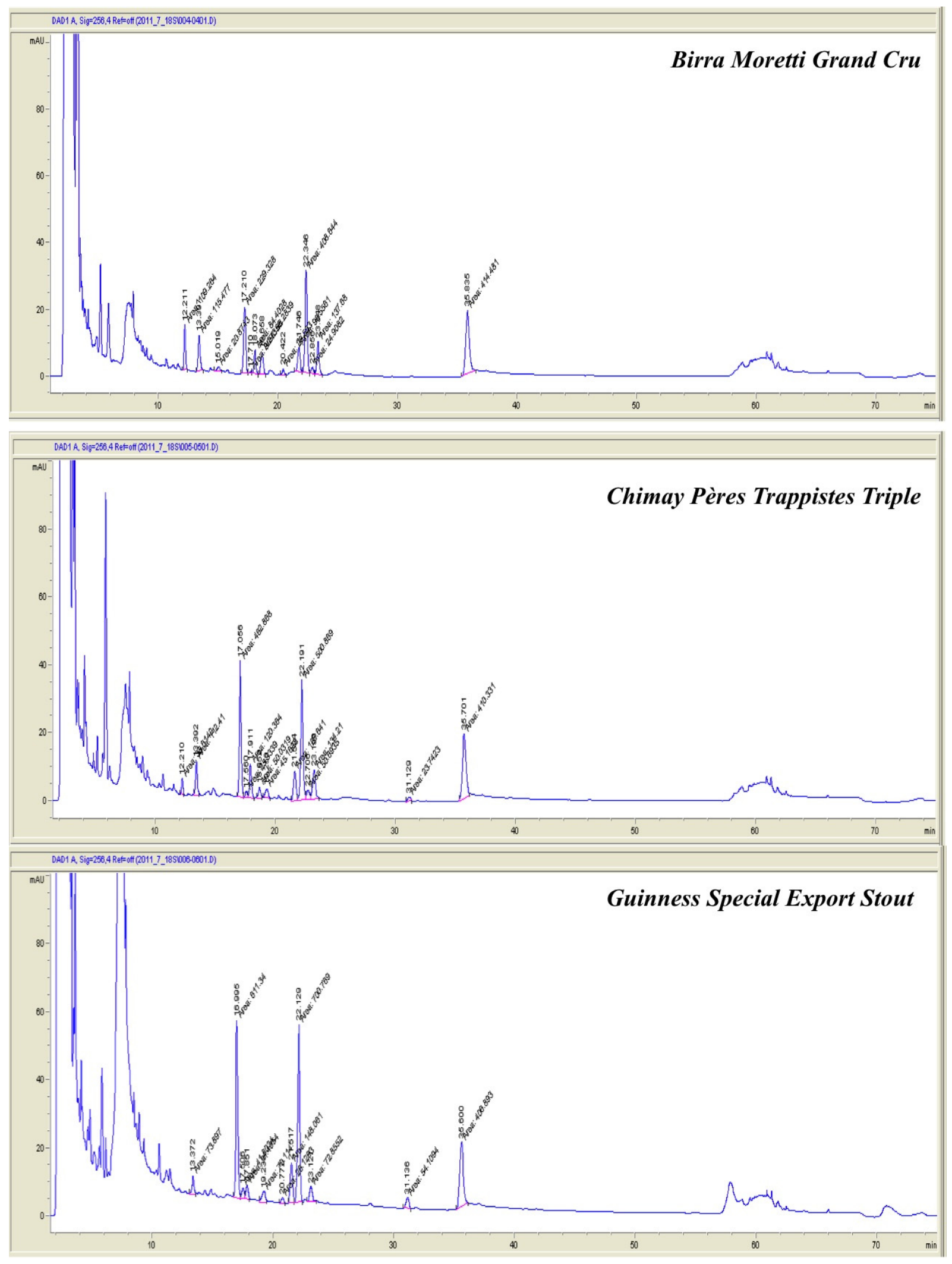

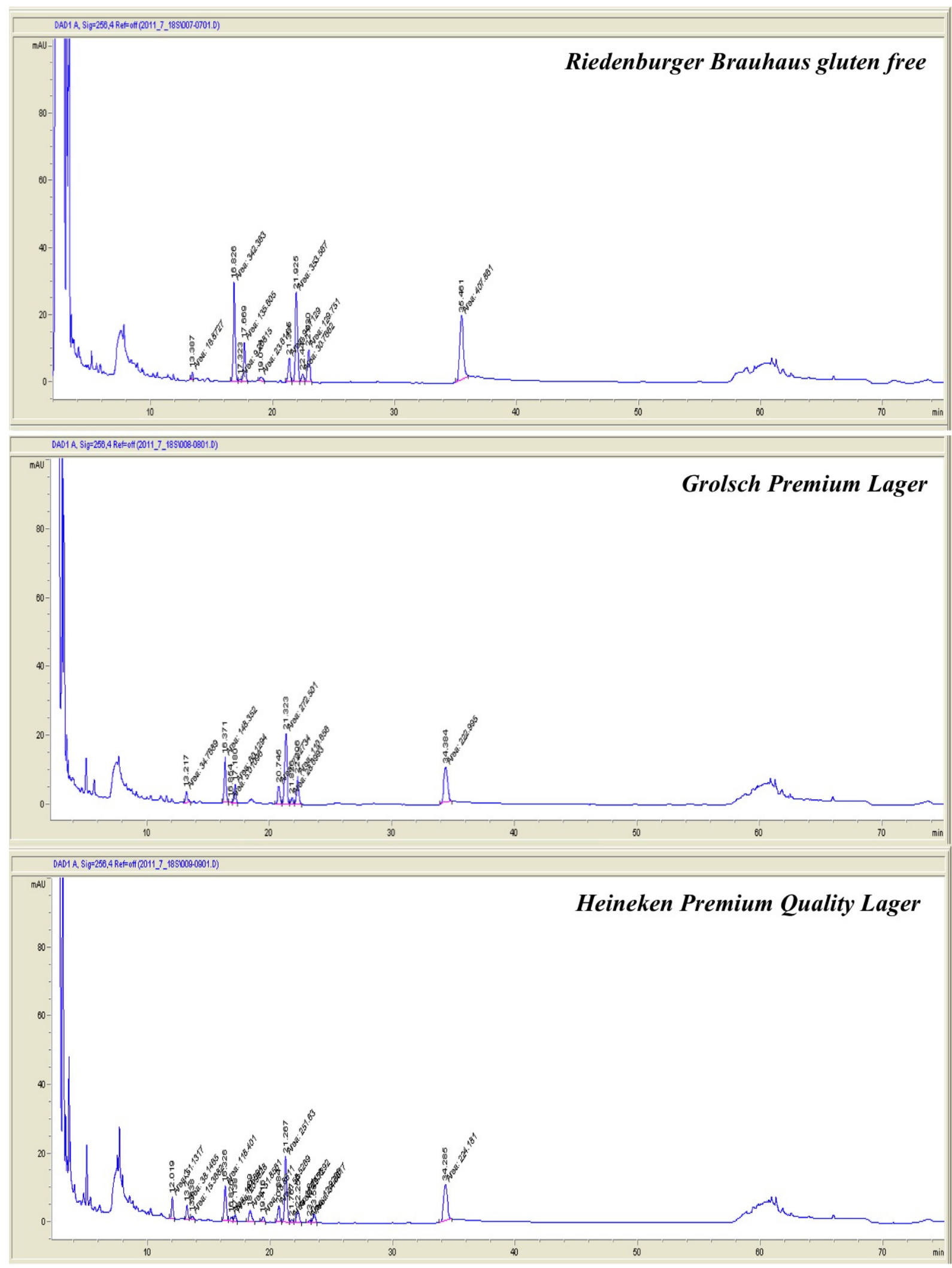

Figure 1. Chromatograms of $\alpha$-acids, iso- $\alpha$-acids and reduced iso- $\alpha$-acids and antioxidants of the commercial beers

Among dihydro-iso- $\alpha$-acids, the presence of DH1 (cis-dihydro-isocohumulone), DH2 (trans-dihydro-isocohumulone), DH4 (cis-dihydro-iso-n-humulone), and DH6 (cis-dihydro-iso-n-humulone) was observed in all beers although in variable concentrations whereas DH3 (cis-dihydro-isoadhumulone) was not 
detected in Aecht Schlenkerla Rauchbier Weizen and Cuveè De Ranke. DH3 tends to disappear after reduction to the tetra- form and, being the least polar, does not survive to the brewing process well.

TH1 (cis-tetrahydro-isocohumulone) was the only tetrahydro-iso- $\alpha$-acid detected and its presence was found in 3 beers, Guinness Special Export Stout, Cuveè De Ranke, and Chimay Pères Trappistes Triple, in the average concentrations of $27.5,13.9$, and $12.9 \mathrm{mg} / \mathrm{L}$, respectively.

The co-derivatives can determine undesirable sensorial properties whereas the beers with high concentrations of $\mathrm{n}$ - and ad-isohumulones are characterized by a finer bitter taste. The ratio between cis and trans forms affects the flavour stability (Vanhoenacker et al., 2004).

The beers having the highest total peak areas were Guinness Special Export Stout (2154.09), ChimayPèresTrappistes Triple (1781.62), and Green King IPA (1754.43). The lowest values of this index were detected in Cuveè De Ranke (832.16), Heineken Premium Quality Lager (834.17), and RiedenburgerBrauhaus gluten free (746.50).

\subsection{Total Phenolic Content}

The total phenolic contents were strongly affected by the beer style (Table 5). Among the beers investigated, the lowest phenolic concentrations were detected on the Riedenburger Brauhaus gluten free, whereas the highest values were measured on the Guinness Special Export Stout. The experimental data can be easily explained. First of all, the beer phenolic contents mainly derive from the cereal used in its production. Furthermore, the phenolic content of barley is higher than those of gluten free cereals such as corn and rice (Hodzic et al., 2009). Sorghum and millet are other cereals used for production of gluten free beer. They have phenolic contents respectively higher than and equal to those of barley (Dykes \& Rooney, 2007) but are usually employed in small amounts and in mixtures with other sugar sources (agave syrup, for example) and, for these reason, they poorly contribute to the beer final phenolic content.The phenolic contents of the two lager beers were very low if compared to those of the other types, confirming the results previously obtained by Granato, Favalli Branco, de Assis Fonseca Faria, and Cruz (2011) in a study on Brazilian lager and brown ale beers.

Table 5. Total phenolic content and antioxidant activity

\begin{tabular}{|c|c|c|c|c|}
\hline \multirow{2}{*}{ Brand } & \multicolumn{2}{|c|}{ mggallic acid eq per } & \multicolumn{2}{|c|}{ Mmol Troloxeq per } \\
\hline & L beer & kg dry matter & L beer & kg dry matter \\
\hline Aecht $\quad$ Schlenkerla & & & & \\
\hline Rauchbier Weizen & $678 \pm 1 \mathrm{f}$ & $13229 \pm 16 \mathrm{f}$ & $0.10 \pm 0.01 \mathrm{f}$ & $1.98 \pm 0.27$ d.e \\
\hline Greene King IPA & & & & \\
\hline Export & $486 \pm 4 \mathrm{c}$ & $9487 \pm 83 \mathrm{c}$ & $0.08 \pm 0.00 \mathrm{~d}$ & $1.73 \pm 0.06 \mathrm{c}$ \\
\hline Cuveè De Ranke & $660 \pm 2 \mathrm{e}$ & $12864 \pm 32 \mathrm{e}$ & $0.09 \pm 0.00$ e.f & $2.38 \pm 0.05 \mathrm{f}$ \\
\hline Moretti Grand Cru & $521 \pm 16 \mathrm{~d}$ & $10156 \pm 321 \mathrm{~d}$ & $0.10 \pm 0.00 \mathrm{f}$ & $1.96 \pm 0.07$ d.e \\
\hline Chimay & & & & \\
\hline Trappistes Triple & $697 \pm 8 \mathrm{~g}$ & $13585 \pm 165 \mathrm{~g}$ & $0.13 \pm 0.03 \mathrm{f} . \mathrm{g}$ & $2.87 \pm 0.66 \mathrm{~g}$ \\
\hline $\begin{array}{l}\text { Guinness } \quad \text { Special } \\
\text { Export Stout }\end{array}$ & $930 \pm 31 \mathrm{~h}$ & $18142 \pm 611 \mathrm{~h}$ & $0.14 \pm 0.01 \mathrm{~g}$ & $2.08 \pm 0.13 \mathrm{e}$ \\
\hline $\begin{array}{l}\text { Grolsch } \quad \text { Premium } \\
\text { Lager }\end{array}$ & $370 \pm 53 b$ & $7206 \pm 1040 b$ & $0.07 \pm 0.00 \mathrm{c}$ & $1.87 \pm 0.11 \mathrm{~d}$ \\
\hline $\begin{array}{l}\text { Heineken Premium } \\
\text { Quality Lager }\end{array}$ & $398 \pm 6 b$ & $7771 \pm 116 b$ & $0.05 \pm 0.00 \mathrm{~b}$ & $1.33 \pm 0.06 \quad b$ \\
\hline Riedenburger & & & & \\
\hline Brauhaus gluten free & $279 \pm 8 \mathrm{a}$ & $5433 \pm 151 \mathrm{a}$ & $0.03 \pm 0.01 \mathrm{a}$ & $0.42 \pm 0.19 \mathrm{a}$ \\
\hline
\end{tabular}

In column. different letters indicate significant differences at $p<0.05$ by LSD multiple range test.

\subsection{Antioxidant Activity}

As observed in Table 5, a wide range of antioxidant activities was obtained for the beers under study, which varies according to the brewing materials and style. These results are in agreement with those reported by 
Piazzon, Forte, and Nardini (2010), who also found this variability among different beers. The highest values (about 4.5 fold higher than the antioxidant capacity of the gluten free beer) were measured in stout and Belgian ale beers.

Concerning the contribution of $\alpha$-acids (one of the classes of phenolic compounds) to the antioxidant activity of beer, several authors (Ting, Lusk, Refling, Kay, \& Ryder, 2008; Wietstock, 2011) found that they $a$ ) form stable phenoxyl radicals that act directly as antioxidants, b) may suppress the initiation through chelating functionality, and c) reduce the formation of radicals. Nevertheless, a higher antioxidant ability is attributed to other classes of phenolics, represented by prenylflavonoids (in particular, flavan-3-ols) and their condensed products, the proanthocyanidins. The ability of flavan-3-ols and proanthocyanidins to act as radical scavenging is due to their particular electron configurations. In fact, flavan- 3-ols readily donate electrons to free radical species, resulting in radicals that are generally more stable than the initial radical species. Proanthocyanidin oligomers, which derive from semi-quinone radicals coupled through nucleophilic addition, retain the antioxidant potential of flavan-3-ols in an extension that depend on substitution patterns, stereochemistry, and inter-flavanoid bond orientation (RiceEvans, Miller, \& Paganga, 1998; de Freitas, Glories, \& Laguerre, 1998). These compounds are readily oxidizable and capable of hindering or preventing the oxidation of other molecules present in beer. Several reports indicate that in beers with high polyphenol contents, these compounds have a stabilizing effect on the degradation of iso- $\alpha$-acids (Malfliet et al., 2008). Other authors (Vinson, Mandarano, Hirst Trevithick, \& Bose, 2003) measured the quality of beer antioxidants by the dose-response inhibition of lower density lipoprotein oxidation. They found that the polyphenols of lager beers exerted interesting effects in terms of reduction of the atherosclerosis incidence.

In agreement with previous researches (Piazzon et al., 2010; H. Zhao, Li, Sun, Yang, \& M. Zhao, 2012), our experimental values of antioxidant activity strictly correlated with the total phenolic contents (1) whereas were poorly correlated with the iso- $\alpha$-acid amounts (2). The relative equations are reported below:

$$
\text { TEAC }(\text { mmol/ L })=0.0001 * T P C(\text { mggallicacideq } / L)+0.0067 R=0.9112 p<0.05
$$

and

$$
\operatorname{TEAC}(\mathrm{mmol} / \mathrm{L})=0.0001 * \text { Iso }-\alpha-\operatorname{acids}(\text { area })+0.0362 R=0.4961 p<0.05
$$

\subsection{Beer Styles}

In order to check the possibility to discriminate the beers studied on the basis of the labelled type/style, the Principal Component Analysis was applied to all parameters investigated with the exception of those that did not show significant differences due to the processing. The resulting graphs (Figure 2a and b) illustrate the relationships among beer samples. The points represent the mean values of each beer sample. The first two principal components (Factor 1 and 2) accounted only for 46.20 and $21.71 \%$ of the explained variance, respectively. As it can be observed, beers were not clearly separated according to the declared style/type. High, low and spontaneous fermentation beers were mixed on the factor plane. Only Riedenburger Brauhaus gluten free, Greene King IPA Export, and Guinness Special Export Stout were distinguishable according to the Factor 1 due to their high specificity. The results of the Principal Component Analysis did not coincide with the classification of beers on the basis of the labelled brewing styles. In fact, all the high and low fermentation beers types investigated in this work were included in a great and heterogeneous group. The only exceptions were represented by the Riedenburger Brauhaus gluten free beers (perhaps for the employment of malts different from the barley malts) and the Guinness Special Export Stout. Nevertheless, this was an expected result since the beer styles don't represent a compositional or legal classification but they are rather used to indicate commercial types. 
b)

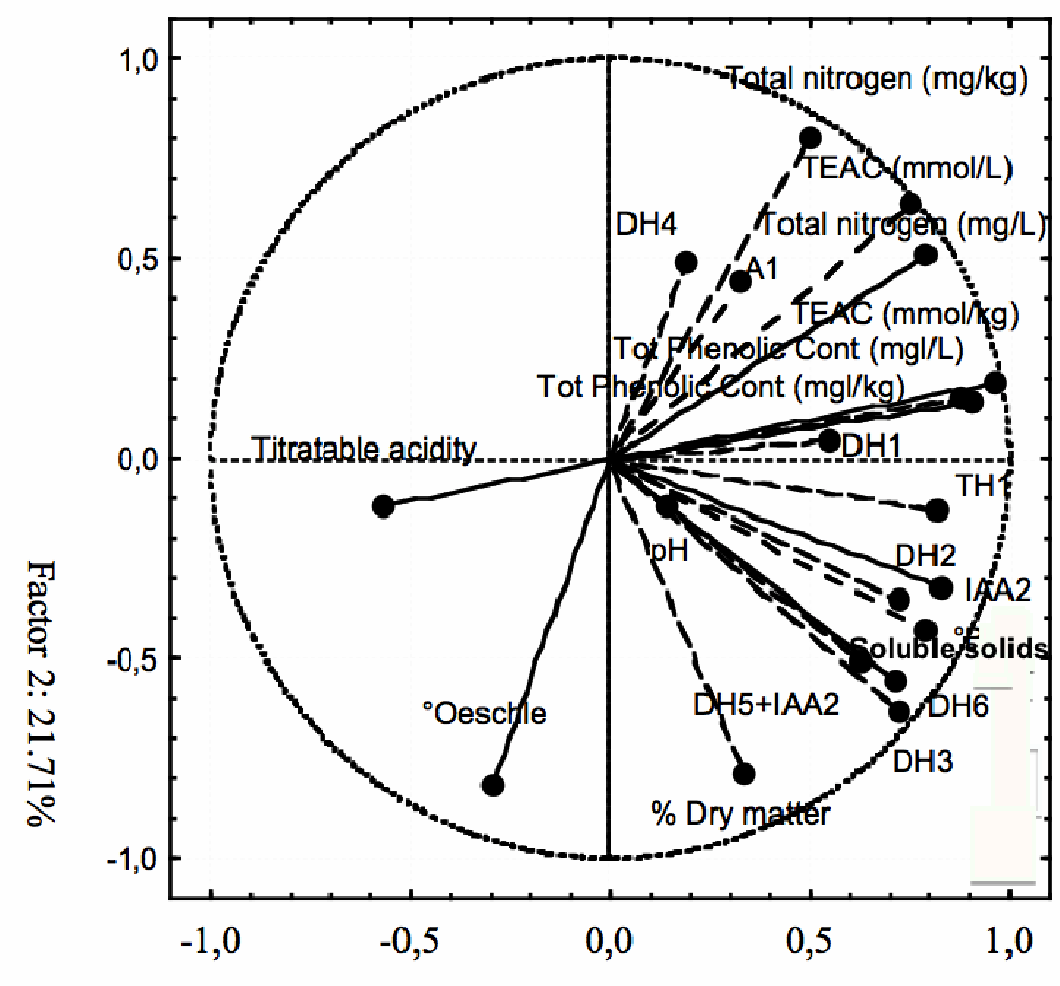

Factor $1: 46.20 \%$

a)

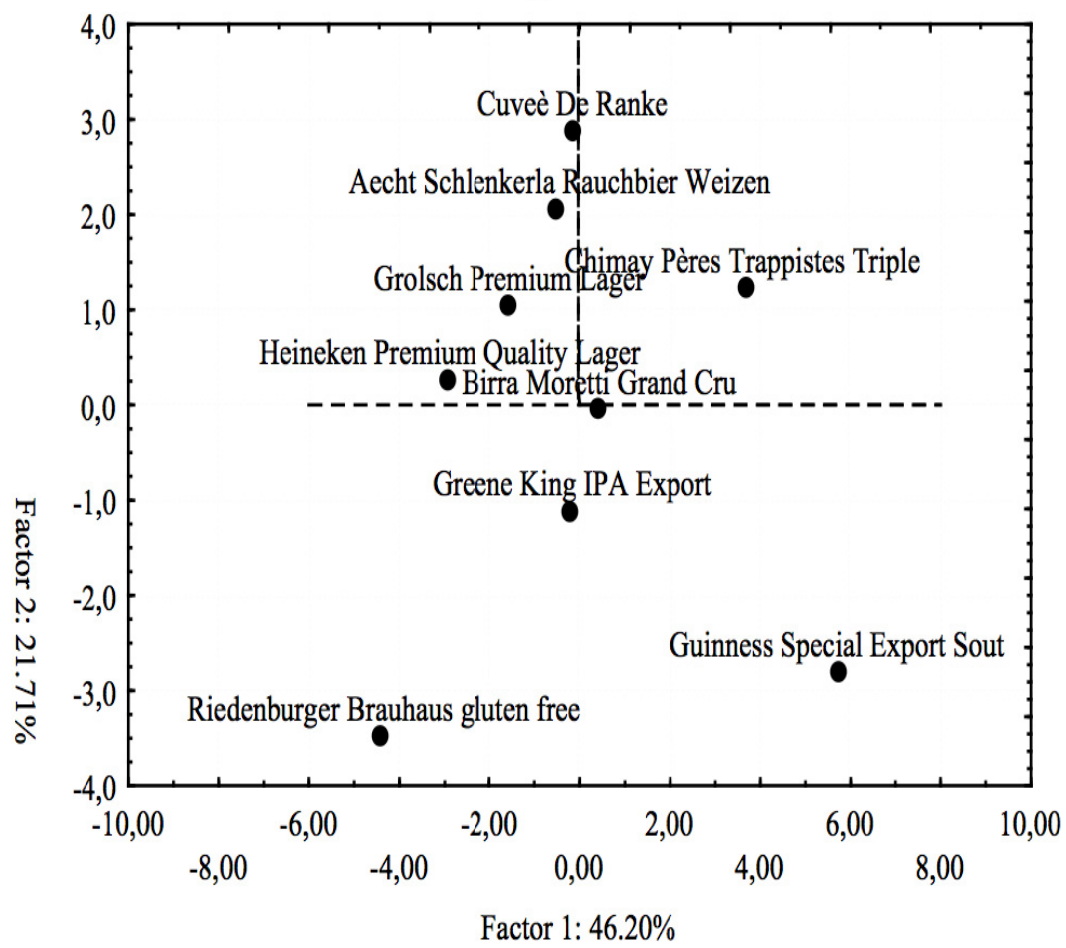

Figure 2. PCA of physical-chemical indices, iso- $\alpha$-acids, and antioxidants of the commercial beer investigated: a) projection of the samples on the factor plane; $b$ ) projection of the variables 


\section{Conclusions}

The work was aimed to make a survey on seven high and two low fermentation beers. The chemical and physical composition of the investigated samples was extremely variegated and not always corresponded to characteristics usually attributed to the beer styles they belong, since the styles generally are big clusters that include products greatly differentiated. The antioxidant activity strictly depended on the total phenolic content and was less influenced by the class of iso- $\alpha$-acids, in agreement with literature. The trans-dihydro-isocohumulone was the most represented iso- $\alpha$-acids, together with the $\alpha$-acid cohumulone. The gluten free beer showed the lowest phenolic and, consequently, the lowest antioxidant activity probably due to the use in its formulation of raw materials poor in such compounds. The two lager beers showed phenolic contents and antioxidant activities lower than all the high fermentation beers with the exception of the gluten free one. In fact, the health benefits of beers are related to the antioxidant prenylflavonoids contained in hops and high fermentation beers are generally hopped more than the lager ones. The Principal Component Analysis failed in classifying beers between high and low fermentation types, which were included in a great and heterogeneous group with the exception of the Riedenburger Brauhaus gluten free beers and the Guinness Special Export Stout.

\section{References}

AOAC International Methods. (1984). Method 10.051, Total nitrogen. Gaithersburg, Maryland, USA.

Asano, K., Shinagawa, K., \& Hashimoto, N. (1982). Characterization of haze-forming proteins of beer and their roles in chill haze formation. Journal of the American Society of Brewing Chemists, 40, 147-154.

Bamforth, C. W. (2004). Beer health and nutrition. Oxford, Great Britain: Blackwell Publishing Ed.

Belgian Royal Decree. (1993). Belgisch Staatsblad/Moniteur Belge, pp. 13507-13509.

Brand-Williams, W., Cuvelier, M. E., \& Berset, C. (1995). Use of a free radical method to evaluate antioxidant activity. LWT-Food Science and Technology, 28, 25-30. http://dx.doi.org/10.1016/S0023-6438(95)80008-5

Curioni, A., Pressi, G., Furegon, L., \& Peruffo, D. B. (1995). Major proteins of beer and their precursors in barley: electrophoretic and immunological studies. Journal of Agricultural and Food Chemistry, 43, 2620-2626. http://dx.doi.org/10.1021/jf00058a013

deFreitas, V. A. P., Glories, Y., \& Laguerre, M. (1998). Incidence of molecular structure in oxidation of grape seed procyanidins. Journal of Agricultural and Food Chemistry, 46, $376-382$. http://dx.doi.org/10.1021/jf970468u

Dykes, L., \& Rooney, L. W. (2007). Phenolic compounds in cereal grains and their health benefits. Cereal Foods World, 52, 105-111. http://dx.doi.org/10.1094/CFW-52-3-0105

European Beer Guide. (2006). World Beer Production. Retrieved June 13, 2012 from http://www.europeanbeerguide.net/eustats.htm\#production

Granato, D., Favalli Branco, G., de Assis Fonseca Faria, J., \& Cruz, G. (2011). Characterization of Brazilian lager and brown ale beers based on color, phenolic compounds, and antioxidant activity using chemometrics. Journal of the Science of Food and Agriculture, 91, 563-571. http://dx.doi.org/10.1002/jsfa.4222

Guido, L. F., Boivin, P., Benismail, N., Gonçalves, C. R., \& Barros, A. A. (2002). An early development of the nonenal potential in the malting process.European Food Research and Technology, 220, $200-206$. http://dx.doi.org/10.1007/s00217-004-1079-y

Hodzic, Z., Pasalic, H., Memisevic, A., Srabovic, M., Saletovic, M., \& Poljakovic, M. (2009). The influence of total phenols content on antioxidant capacity in the whole grain extracts. European Journal of Scientific Research, 28, 471-477.

Lu, J., Zhao, H., Chen, J., Fan, W., Dong, J., Kong, W., ... Cai, G. (2007). Evolution of phenolic compounds and antioxidant activity during malting. Journal of Agricultural and Food Chemistry, 55, 10994-11001. http://dx.doi.org/10.1021/jf0722710

Malfliet, S., Van Opstaele, F., De Clippeleer, J., Syrzin, E., Goiris, K., De Cooman, L., \& Aerts, G. (2008). Flavor instability of pale lager beers: Determination of analytical markers in relation to sensory ageing. Journal of the Institute of Brewing, 114, 180-192.

NREL. (2007). Theoretical ethanol yield calculator. Washington, D.C.: U.S. Department of Energy. Retrieved from www.eere.energy.gov/biomass/ethanol_yield_calculator.html 
Piazzon, A., Forte, M., \& Nardini, M. (2010). Characterization of phenolic content and antioxidant activity of different beer types. Journal of Agricultural and Food Chemistry, 58, 10677-10683. http://dx.doi.org/10.1021/jf101975q

Rice Evans, C. A., Miller, N. J., \& Paganga, G. (1998). Structure-antioxidant activity relationships of flavonoids and phenolic acids. Free Radical Biology \& Medicine, 20, 933-956. http://dx.doi.org/10.1016/0891-5849(95)02227-9

Singleton, V. L., \& Rossi, J. A. (1965). Colorimetry of total phenolics with phosphomolybdicphosphotungstic acid reagents. American Journal of Enology and Viticulture, 16, 144-158.

Ting, P., Lusk, L., Refling, J., Kay, S., \& Ryder, D. (2008). Identification of antiradical hop compounds. Journal of the American Society of Brewing Chemists, 66, 116-126.

Vanhoenacker, G., De Keukeleire, D., \& Sandra, P. (2004). Analysis of iso- $\alpha$-acids and reduced iso- $\alpha$-acids in beer by direct injection and liquid chromatography with ultraviolet absorbance detection or with mass spectrometry. Journal of Chromatography A, 1035, 53-61. http://dx.doi.org/10.1016/j.chroma.2004.02.038

Vinson, J. A., Mandarano, M., Hirst, M., Trevithick, J. R., \& Bose, P. (2003). Phenol antioxidant quantity and quality in foods: beers and the effect of two types of beer on an animal model of atherosclerosis. Journal of Agricultural and Food Chemistry, 51, 5528-5533. http://dx.doi.org/10.1021/jf034189k

Wietstock, P. (2011). Incremental hop dosage regime to improve the oxidative beer stability. Oral presentation at the MBAA Convention 2011, Minneapolis USA.

Zhao, H., Fan, W., Dong, J., Lu, J., Chen, J., Shan, L., Lin, Y., \& Kong, W. (2008). Evaluation of antioxidant activities and total phenolic contents of typical malting barley varieties. Food Chemistry, 107, 296-304. http://dx.doi.org/10.1016/j.foodchem.2007.08.018

Zhao, H., Li, H., Sun, G., Yang, B., \& Zhao, M. (2012). Assessment of endogenous antioxidative compounds and antioxidant activities of lager beers. Journal of the Science of Food and Agriculture.

\section{Copyrights}

Copyright for this article is retained by the author(s), with first publication rights granted to the journal.

This is an open-access article distributed under the terms and conditions of the Creative Commons Attribution license (http://creativecommons.org/licenses/by/3.0/). 